УДК 351.745:061.1

DOI https://doi.org/10.32837/apdp.v0i83.125

\title{
С.В.Медведенко
}

\section{ЗАРУБІЖНИЙ ДОСВІД ВЗАСМОДІї ПОЛІЦІї З ГРОМАДСЬКІСТЮ НА ПРИКЛАДІ ВЕЛИКОБРИТАНІЇ ТА БЕЛЬГІЇ}

Постановка проблеми. Сучасні умови та стан розвитку суспільства вимагають актуальних підходів до здійснення поліцейської діяльності. Прагнення України інтегруватися в європейську спільноту та відповідати загальноєвропейським стандартам, зокрема і в правоохоронній сфері, спонукають до пошуку нових шляхів, відмови від старих методів, вимагають від правоохоронних органів бути більш відкритими для суспільства, служити людям, використовуючи сучасні засоби та нові ефективні методики. Досвід інших країн у здійсненні правоохоронної діяльності, взаємодії та співпраці з громадянами, залученні громадськості до забезпечення правопорядку та безпечного середовища є цінним джерелом інформації, яке не лише можливо, а й потрібно використовувати, відібравши найбільш вдалі та придатні для умов і особливостей нашої країни форми та методи.

Аналіз останніх досліджень і публікацій. Слід зазначити, що провідними для багатьох поліцейських структур є принципи правоохоронної діяльності викладені сером Робертом Пілем видатним британським державним діячем першої половини XIX сторіччя, завдяки якому в 1829 році була заснована Лондонська муніципальна поліція.

Один із принципів дуже чітко підкреслює місце поліції в суспільстві та роль суспільства, громадськості в правоохоронній діяльності: «Поліція в усі часи повинна підтримувати відносини з громадськістю, дотримуючись історичної традиції, що поліція - це громадськість, а громадськість - це поліція; поліція це єдині представники громадськості, яким платять за те, щоб вони працювали повний робочий день виконуючи обов' язки, які покладені на кожного громадянина з метою підтримання суспільного добробуту» [1].

Країни Європи дотримуються загальноєвропейських стандартів поліцейської діяльності, але кожна 3 них має свою історію розвитку правоохоронних органів, особливості звичаїв та менталітету населення, специфіку, а отже і окремі особливості та форми взаємодії поліції та населення.

Структуру поліції Великобританії складають підрозділи поліції Англії, Північної Ірландії, Шотландії, Уельсу, а також Національні спеціальні поліцейські сили (Британська транспортна поліція, Цивільна ядерна поліція, Поліція Міністерства оборони, Авіаційна служба Національної поліції). Великобританія є країною, де взаємодія з громадськістю є досить розвиненою та має багато форм. Офіційний сайт поліції Великобританії пропонує достатньо велику кількість інформації для бажаючих бути волонтерами та надавати допомогу поліції у забезпечення правопорядку. Кожна особа може обирати, яким чином допомагати поліції.

«Спеціальні констеблі» - група підготовлених добровольців, які підтримують місцеву поліцію та працюють разом з нею. Спеціальними констеблями можуть ста- 
ти будь-які громадяни незалежно від професії, які пройшли спеціальну підготовку. Спеціальні констеблі мають такі самі повноваження як і поліцейські, навіть носять таку саму форму, але працюють не більше 4-х годин на тиждень у місцевій поліції. Беручи участь в усіх аспектах діяльності поліції (відповідають на дзвінки, патрулюють, працюють в школах, надають допомогу в різних ситуаціях, контролюють та регулюють дорожній рух тощо), спеціальні констеблі є прямим зв'язком поліції і громади, адже самі є її представниками [2; 3].

Наступною формую участі громадськості в діяльності поліції є поліцейські волонтери Police Support Volunteers (PSV) - це цивільні добровольці, які витрачають свій час на допомогу у виконанні завдань, які доповнюють обов'язки, що виконуються співробітниками поліції і іншим персоналом поліції, що допомагає звільнити офіцерів і персонал для виконання ключових оперативних обов'язків. Функціями добровольців є як надання послуг по боротьбі зі злочинністю та адміністративної діяльності, так і відстеження повідомлень про злочини та інциденти з представниками громадськості. Діяльність поліцейських волонтерів приносить значну користь поліцейській службі і місцевим громадам.

У Великобританії в Моллінгтоні Чешир у 1982 році було створено мережу Ноте Watch, яка з часом розвинулась та отримала назву Neighborhood Watch and Home Watch Network (NHWN). Ця мережа об’єднує сусідів, створюючи сильні, доброзичливі спільноти, зменшуючи рівень злочинності та антигромадської поведінки. Учасники цієї мережі можуть використовувати ії ресурси для знайомства, обміну знаннями, реалізації планів діяльності тощо. В Англії та Уельсі нараховується понад 170000 формувань Neighborhood Watch i Home Watch Network (далі - NHWN) [2].

NHWN прагне підтримувати і розвивати міцні робочі стосунки на всіх рівнях: державному, національному та місцевому для того, щоб сприяти досягненню спільної мети з попередження правопорушень та забезпечення безпеки людей в їх громадах. NHWN тісно співпрацює з Національною радою начальників поліції, зокрема з головним констеблем, який очолює напрям «Громадяни і охорона правопорядку», з Асоціацією поліцейських і Коледжем поліції.

NHWN використовує системне забезпечення Neighborhood Alert для зв'язку з людьми та реєстрації координаторів, Neighborhood Watch. Neighborhood Alert забезпечує безперешкодний обмін інформацією. Кінцевий користувач (особа) вибирає, які організації, окрім його координатора, можуть «бачити» його дані, чи хоче він бути видимим для поліції, Neighborhood Watch або обом організаціям [4].

У різних місцевостях система оповіщення сусідів відома під іншими назвами: "In The Know" у Ланкаширі, "Есорs" у Кембриджширі і “Alert Thames Valley" в долині Темзи, іноді люди називають Neighborhood Watch як Our watch через доменне ім'я. I хоча імена різні, всі системи працюють, використовуючи одне програмне забезпечення. Кожен підрозділ поліції має «єдиний пункт зв’язку» (SPOC) для вирішення питань спостереження. Ним, як правило, також користуються мережі нагляду за фермами, конями, собаками, хоча офіційно вони не є частиною мережі Neighborhood Watch [4].

Благодійна організація Crimestoppers «зупини злочинця», де працюють більше 500 добровольців, допомагає знайти злочинців і розкрити злочини. Вона надає 
можливість особам здійснити анонімний дзвінок на цілодобовий номер, щоб надати інформацію про злочин; або, як альтернативний варіант, люди можуть надіслати інформацію анонімно через веб-сайт Crimestoppers. Також Crimestoppers надає поради як захистити своїх близьких від злочинності, щоб кожен міг відчувати себе в безпеці. Після отримання дзвінка або заповненої анонімної онлайн-форми створюється звіт, в якому міститься надана інформація, звіт перевіряється на предмет неможливості ідентифікувати особу, що надала інформацію. Після чого звіт направляється до відповідного органу: місцевої поліції або іншого органу відповідно до повноважень.

Діяльність організації Crimestoppers є важливою і необхідною через те, що люди не бажають звертатися до поліції напряму через низку причин:

1) не бажають спілкуватися з поліцією;

2) необхідно надати інформацію відносно осіб, яких вони знають;

3) хвилюються, що інші особи знатимуть, про звернення до поліції;

4) не впевнені, що інформація допоможе;

5) не хочуть мати справу з судами.

Якщо передана інформація викликає сумніви в її достовірності та меті надання, то Crimestoppers співпрацюють зі співробітниками правоохоронних органів, щоб перевірити інформацію та встановити її джерело.

Особа може отримати грошову винагороду до 1000 фунтів стерлінгів за інформацію, реалізація якої призвела до затримання, арешту і засудження правопорушника, або є надзвичайно корисною для правоохоронних органів. Будь-яка особа може надати допомогу організації Crimestoppers шляхом пожертви, участі в Лондонському марафоні, відрахування з заробітної плати (яке здійснюється до податкового відрахування, що дозволяє зекономити на податках) або надати добровільну допомогу організації [5].

Гаслом вуличних пасторів (Street Pastors) Великобританії $є$ «Ми піклуємось, слухаємо, допомагаємо». Вуличні пастори - це спеціально підготовлені волонтери з місцевих церков, які дбають про свою громаду. Вони групами з чоловіків і жінок патрулюють вулиці, як правило, по п’ятницях і суботах з 10 години вечора до 4 години ранку. Вуличний пастор - це церковний лідер або служитель церкви чи іï член, який дбає про суспільство, особливо про молодих людей, які відчувають себе обділеними і маргіналізованими. Вуличні пастори, спілкуючись із людьми на вулицях, забезпечують участь церкви у вирішенні міських проблем.

Керує діяльністю вуличних пасторів Фонд Вознесіння (Ascension Trust) при підтримці місцевих церков і суспільних груп в партнерстві з поліцією, місцевою радою та іншими статутними установами [6]. Часто разом з ними по вечорах п’ятниці та суботи працюють представники волонтерської організації Halifax Street Angels Вуличні янголи - волонтери, які надають допомогу спільноті та громадянам, так само співпрацюючи з поліцією та місцевою владою на благодійних та добровільних засадах [7].

Національна благодійна організація Великобританії Victim support (підтримка жертв) надає безкоштовну та конфіденційну допомогу жертвам злочинів, свідкам, ïх сім'ям, друзям і всім, хто постраждав в Англії, Уельсі та Північній Ірландії. 
Victim support також представляє інтереси жертв і свідків в національному масштабі, надає психологічну та правничу допомогу.

У своїй діяльності Victim support співпрацює з широким колом організацій, серед яких Міністерство юстиції, Національна служба пробації, Рада відновного правосуддя, поліцейський коледж, Асоціація поліцейських криміналістів, Поліція Лондону тощо [8].

Діяльність громадської організації Speedwatch допомагає людям знизити швидкість автомобільного руху в їх районі. Волонтери працюють у межах території своєї спільноти (громади), співпрацюючи з поліцією, щоб підвищити обізнаність про небезпеку перевищення швидкості і допомогти контролювати швидкість автомобільного руху на місцевому рівні.

Незалежна асоціація відвідувачів місць утримання під вартою (“ICVA”) - це організація, що фінансується та підтримується Міністерством внутрішніх справ, і комісаром поліції по боротьбі зі злочинністю (РСС). Місцеві добровольці без попередження відвідують поліцейські ділянки для перевірки дотримання прав, пільг, умов утримання затриманих, про що звітують комісару поліції по боротьбі зі злочинністю та поліцейськими органами, які притягують до відповідальності головних констеблів. Також асоціація здійснює нагляд за відповідністю організації умов утримання під вартою згідно з вимогами міжнародних договорів. Незалежні відвідувачі відіграють важливу роль у дотриманні стандартів та сприянні забезпечення справедливого поводження із затриманими. Їх візити допомагають підвищити підзвітність і прозорість поліції у громадах, яким вони служать [9].

Незалежні консультативні групи - це групи представників спільноти, які регулярно зустрічаються з поліцією для обговорення та вирішення місцевих проблемних питань. Їх діяльність дає можливість поліції отримати зворотний зв’язок від громади та поглянути на проблему з точки зору громади.

Ще однією організацією є Citizens in Policing (громадяни в поліції). Цей термін використовується для опису тисяч людей по всій Великобританії, які використовують свій час, щоб підтримати поліцію, підвищуючи потенціал поліцейських сил, привносячи особисті корисні навички та досвід в поліцейські команди, створюючи більш тісні та ефективні відносини з громадами. Слід приділити особливу увагу Volunteer Police Cadets - добровільним поліцейським кадетам - національній молодіжній організації, метою діяльності якої є не пошук майбутніх поліцейських, а заохочення духу пригод і свідомого громадянства серед ї̈ учасників. Volunteer Police Cadets вважає, що кожна молода людина заслуговує на можливість процвітати незалежно від її походження, і заохочують молодих людей з усіх верств суспільства приєднуватися до VPC, включаючи тих, хто може бути вразливим до впливу злочинності та соціальної ізоляції.

Курсантами є особи віком від 13 до 18 років, які відвідують щотижневі збори тривалістю близько двох годин у складі місцевої кадетської групи протягом семестру. Під керівництвом кадетського лідера-добровольця (який є співробітником поліції, спеціальним констеблем, PCSO, співробітником поліції або цивільним добровольцем), курсанти проводять структуровану програму навчання в галузі права і поліцейської діяльності, проходять ряд етапів навчання перед атестацією та про- 
ходженням параду. Курсанти отримують уніформу і навчаються бути дисциплінованими і незалежними, а також виконують базові тренування. В основі кадетської програми лежить почуття спільності і громадянства, програма допомагає молоді робити позитивний життєвий вибір і дозволяє їм впливати на своє оточення [10].

Поліція Великобританії в першу чергу виступає в якості «моральних стражів» соціальної стабільності і порядку, які відповідають за суспільні цінності та неформальний соціальний контроль, і лише потім в якості правоохоронного органу. Поліція Бельгії складається з федеральної поліції та місцевої поліції. Ці два рівні поліції разом забезпечують функціонування інтегрованої поліції. Вони є автономними та залежать від різних органів влади.

Метою федеральної поліції є підвищення внутрішньої безпеки та забезпечення демократії в країні. Як правило, федеральна поліція виконує завдання адміністративної та судової поліції, а також надає спеціалізовану підтримку підрозділам місцевої поліції. У своїй діяльності вона постійно та тісно співпрацює з місцевою поліцією.

До зони обслуговування місцевої поліції входить одна або декілька громад (муніципалітетів). Кожна зона поліції має один корпус місцевої поліції. Коли зона складається з кількох громад. Місцева поліція організована у такий спосіб, щоб мати один або декілька відділів поліції у кожній громаді, що входить до цієї зони [11, с. 136$]$.

Якщо зона обслуговування поліції складається з кількох громад, то в такому випадку вона управляється поліцейською радою. До її складу входять мер міста або мери міст, якщо їх кілька, представники громад відповідно до кількості населення, але не менше одного представника від громади. Після обрання члени поліцейської ради приймають присягу перед президентом поліцейської колегії.

Місцева поліція здійснює організаційні заходи та надає завдання місцевому поліцейському корпусу, який знаходиться під керівництвом мера. Рада громади або поліцейська рада відіграє важливу роль у діяльності поліції. Окрім зазначеного вище, вона: визначає штат персоналу, призначає поліцейських зі складу кандидатів, визнаних придатними відбірковою комісією, інших категорій працівників (адміністративний, логістичний, технічний персонал) тощо.

Визначальною для поліції Бельгії є філософія «поліцейська діяльність на рівні громади», вона направлена на інтеграцію поліції в спільноту, служінню громадянам та спільний з громадами пошук рішень з урахуванням місцевих особливостей задля забезпечення правопорядку.

Діяльність бельгійської поліції, орієнтованої на допомогу громадськості, грунтується на п'яти основних принципах:

1) зовнішня орієнтація,

2) вирішення проблем,

3) партнерство,

4) відповідальність (підзвітність),

5) компетентна участь (розширення прав і можливостей).

Зовнішня орієнтація означає, що поліція не поза суспільством, а в середині нього. Поліція знаходиться в суспільстві, як його частина, і може діяти ефективно тільки інтегруючись в суспільство, спільноту, для чого вирішальне значення ма- 
ють присутність, постійність і обмін. Інтеграція поліції дозволяє визначити, що їі щоденна діяльність пов'язана із забезпеченням безпеки та якості життя в суспільстві і в кожній конкретній громаді, в результаті чого поліція своєчасно і належним чином реагує на ситуації та може їх передбачати. Орієнтація на суспільство реалізується шляхом сервіс-орієнтованого підходу до надання поліцейських послуг, відповідно до потреб і очікування громади.

Принцип вирішення завдань та проблем реалізується через проблемно-орієнтований підхід до забезпечення безпеки. Він означає, що люди та поліція не просто реагують на інциденти, а реагуючи діють відповідним чином. Поліція повинна визначати причини проблем і намагатися цілеспрямовано їх усувати. Дотримання такого проактивного принципу допомагає запобігати та вирішувати проблеми в короткостроковій і довгостроковій перспективі.

Партнерство означає усвідомлення поліцією того, що не тільки вона несе відповідальність за забезпечення безпеки та якості життя. Необхідно працювати разом з громадою. Партнерство грунтується на переконаності в тому, що безпека і якість життя з'являються лише завдяки спільній роботі всіх ланок, кожен партнер формує ланку глобального та комплексного підходу.

Принцип відповідальності (підзвітності) означає, що поліція відповідає та звітує перед громадою за свій внесок в забезпечення потреб громади в безпеці та якості життя.

Принцип компетентної участі (розширення прав і можливостей) реалізується через створення можливостей як для поліцейських служб, так і для населення спільно вирішувати питання безпеки, якості життя, надання послуг та забезпечення правопорядку, а також критично ставитися до виконання власних завдань та способів їх виконання $[12,13]$.

На місцевому рівні в Бельгії взаємодія поліції та громади, зокрема, відбувається з використанням «діалог-кафе». В районах міста або маленьких містечках відповідальні районні інспектори (дільничні поліцейські) за необхідності, але регулярно проводять зустрічі з мешканцями, представниками громади для обговорення проблем, пропозицій щодо їх усунення, вирішення питань безпеки. Ці зустрічі відбуваються в неформальній обстановці, в будь-якому зручному місці, наприклад кафе. На них можуть бути присутніми органи місцевої влади, керівництво поліції. В результаті таких зустрічей під час обговорень відбувається швидке прийняття рішень, узгодження дій і розподіл завдань по повноваженням між відповідальними службами. Окрім того, зустрічі в такому форматі дозволяють поліцейському бути ближче до громади, а громаді сприймати працівників поліції, як своїх членів. Також допомогу поліції при охороні публічного порядку, особливо в зимовий час, надають поліцейські волонтери - молодь, яка планує прийти на службу в поліцію, пенсіонери, або свідомі громадяни.

За співпраці поліції з муніципалітетом та громадянами для забезпечення правопорядку використовується правило трикутника (теорія рутинної діяльності, Л. Коен і М. Фелсон) - правопорушення відбувається там, де збігаються три фактори: мотивований правопорушник (злочинець), відповідна ціль (особа, річ) і умови для скоєння правопорушення (відсутність охорони, легкий доступ, відсутність 
освітлення тощо). Щоб запобігти правопорушенням, необхідно виключити один складник. Так, наявність охорони, використання сигналізації, замків, огорож, сторожових собак, або навіть просто вуличного освітлення може демотивувати правопорушника. Підсилення соціального контролю, дотримання заходів безпеки та запобігання громадянами є дієвим засобом профілактики правопорушень та підвищення рівня безпеки.

«Завжди знай ту громаду, з якою ти працюєш» є основним наголосом у проекті Community Policing and the Prevention of Radicalisation (CoPPRa) для якнайкращого орієнтування поліцейських у тому, що відбувається в суспільстві, та на розбудові партнерських відносин заради спільних із громадами дій і спільної відповідальності за їхні результати. Проект направлений на попередження радикалізації у суспільстві та розрахований насамперед на поліцейських, які працюють «на місцях» і знають місцеві проблеми, оскільки постійно займаються ними відповідно до своїх повноважень [13].

Досвід взаємодії поліції та представників громадськості у Великобританії та Бельгії є дуже різноманітним, має багато форм та ще більшу кількість методів та способів. Зазначене дає можливість підкреслити, що в країнах значну увагу приділяють як формуванню позитивного іміджу поліції, так і питанням партнерства поліції і громади. Поліція є частиною громади і проблеми населення не є сторонніми для поліції. Діяльність поліції Великобританії та Бельгії є доступною та прозорою для громади, для її ефективності залучаються всі верстви населення від кадетів до волонтерів поліції, які можуть допомагати як своїми силами (брати участь у діяльності, здійснювати патрулювання), так і надавати матеріальну допомогу.

Досвід цих країн може бути використаний в Україні з урахуванням особливостей українського законодавства та менталітету населення.

1. Sir Robert Peel's Principles of Law Enforcement 1829. pdf.

2. URL: https://www.durham.police.uk/About-Us/Documents/Peels_Principles_Of_Law_Enforcement.

3. Crime and policing in England, Wales and Northern Ireland. URL: https://www.police.uk/ volunteering/.

4. Metropolitan Police. URL: https://www.met.police.uk/car/careers/met/police-volunteer-roles/. special-constable/special-constable-overview/.

5. Neighborhood Watch. URL: https://www.ourwatch.org.uk/knowledge/faqs-police/.

6. Crimestoppers. URL: https://crimestoppers-uk.org/.

7. Street Pastors. URL: https://www.streetpastors.org/.

8. Halifax Street Angels. URL: https://halifaxstreetangels.org.uk/.

9. Victim support. URL: https://www.victimsupport.org.uk/.

10. Independent Custody Visitors Association. URL: https://icva.org.uk/.

11. Volunteer Police Cadets. URL: https://vpc.police.uk.

12. Статус поліції: міжнародні стандарти і зарубіжне законодавство / За заг. редакцією О.А. Банчука. Київ : Атіка, 2013. 588 с.

13. Federale politie. URL:https://www.politie.be/5998/nl/over-ons/geintegreerde-politie/excellentepolitiezorg.

14. Politiezone Vlas. URL: https://www.pzvlas.be/index.php?id=home. 


\begin{abstract}
Анотація
Медведенко С. В. Зарубіжний досвід взаємодії поліції з громадськістю на прикладі Великобританії та Бельгії. - Стаття.

У статті проаналізовано зарубіжний досвід взаємодії поліції з громадськістю на прикладі Великобританії та Бельгії. Звернуто увагу на міжнародну практику обміну досвідом, шляхом представлення нових напрацювань у сфері профілактики правопорушень.

Встановлено, що на важливість співпраці поліції та суспільства свого часу звернув увагу Роберт Піл в запропонованих ним принципах правоохоронної діяльності, які і досі є актуальними та використовуються поліцією багатьох країн.

Зауважено, що хоча країни Європи додержуються загальноєвропейських стандартів поліцейської діяльності, але кожна з них має свою історію розвитку підрозділів поліції, особливості звичаїв та менталітету населення, специфіку, а отже і окремі особливості та форми взаємодії поліції та населення.

Розглянуто структуру поліції Великобританії, форми і методи, які використовуються підрозділами поліції при роботі з громадянами, групами населення і органами місцевого самоврядування. Відмічено, що приділяється багато уваги якості, кількості та доступності інформації щодо можливостей взаємодії населення з поліцією. Громадянам пропонується різні можливості та варіанти для надання допомоги поліцейським підрозділам чи окремим працівникам або прийняття участі в правоохоронній діяльності.
\end{abstract}

Приділено увагу особливостям побудови системи поліцейських органів та підрозділів Бельгії, розглянуто принципи їі діяльності.

Важливим аспектом діяльності місцевої поліції Бельгії є інтегрування в громаду та побудова партнерських відносин, що допомагає не лише вчасно реагувати, а й запобігати майбутнім правопорушенням.

Зроблено висновок, що аналіз зарубіжного досвіду дозволить уникнути помилок, обрати, адаптувати до умов нашої країни і менталітету населення та використати корисні надбання для вдосконалення взаємодії громадськості і Національної поліції України.

Ключові слова: взаємодія, співпраця, поліція, громадськість, суспільство, зарубіжний досвід.

\title{
Summary
}

Medvedenko S. V. The overseas experience of police-public interaction on the example of the UK and Belgium. - Article.

The paper focuses on the overseas experience of police-public interaction on the example of the UK and Belgium.

Attention is drawn to the international practice of sharing experience by presenting new developments in the field of crime prevention.

It has been established that Robert Peel in his time paid attention to the importance of police and community cooperation in the principles of law enforcement that he proposed, which are still relevant and used by police in many countries.

It is noted that although European countries adhere to the European standards of police activity, each of them has its own history of development of police units, peculiarities of customs and population's mentality, specifics, and therefore individual features and forms of interaction between police and population.

The UK police structure, forms and methods used by police departments in dealing with citizens, populations and local authorities are examined. It is noted that much attention is paid to the quality, quantity and availability of information regarding the possibilities of interaction of population with the police. Citizens are offered various options and variants to assist police units or some employees or to participate in law enforcement.

Attention was paid to the peculiarities of system establishment of police bodies and units of Belgium, and the principles of its activity were considered.

It is noted that an important aspect of the Belgian local police's activities is the integration into the community and the building of partnerships, which helps not only to respond in a timely manner but also to prevent future offenses.

It is concluded that the analysis of foreign experience will help to avoid mistakes, to choose, to adapt to the conditions of our country and the population's mentality and to use the useful assets to improve the interaction of the public and the National Police of Ukraine.

Key words: interaction, cooperation, police, public, society, foreign experience. 